\title{
MOTIVES FOR AND BARRIERS TO THE USE OF ELECTRIC MOPED SCOOTER SHARING SERVICES
}

MOTYWY I BARIERY KORZYSTANIA Z ELEKTRYCZNYCH SKUTERÓW NA MINUTY

\author{
Paweł Bartkowiak \\ Poznań University of Economics and Business \\ Al. Niepodległości 10, 61-875 Poznań \\ pawel.bartkowiak@ue.poznan.pl ORCID 0000-0001-9330-756X \\ Szymon Michalak \\ Poznań University of Economics and Business \\ Al. Niepodległości 10, 61-875 Poznań \\ szymon.michalak@ue.poznan.pl O ORCID 0000-0003-2874-7694 \\ Maciej Młodzik \\ Piasecki University of Physical Education in Poznań \\ Królowej Jadwigi 27/39, 61-871 Poznań \\ maciejml@wp.pl 0 ORCID 0000-0003-3803-8939 \\ DOl: 10.2478/minib-2021-0019
}

\section{ABSTRACT}

In line with the concept of sustainable development, changes in various forms of urban transport have been observed over the past few years, and the implementation of low-emission transport solutions is becoming a priority for local government. One of the key changes observed worldwide taking place on the urban transport market is the dynamic development of various forms of shared micro-mobility. One of these forms are electric moped scooter sharing services and despite their rapid growth in popularity, the existing research contributions on determinants of the use of this micro-mobility mode are limited to only a few studies. The goal of this paper is to advance knowledge regarding the motives and barriers to the use of electric moped scooter sharing services. The paper discusses the results of a study that was carried out in 2021 on a sample of 352 Polish users of electric moped scooter sharing services. The most important reasons for using these services included the convenience of this mobility mode and no city parking costs. The biggest barriers in choosing this micro-mobility mode for Polish consumers were those related to the safety of use.

Key words: shared micro-mobility, shared mobility, moped scooter-sharing, motives, consumer behavior, transport, consumer innovativeness 


\section{ABSTRAKT}

Zgodnie z koncepcją zrównoważonego rozwoju w ostatnich latach obserwuje się zmiany dotyczące różnych form transportu miejskiego, a wdrażanie niskoemisyjnych rozwiązań transportowych staje się priorytetem dla jednostek samorządu terytorialnego. Jedną z kluczowych zmian obserwowanych na całym świecie zachodzących na rynku transportowych jest dynamiczny rozwój różnych form współdzielonej mikromobilności w miastach. Jedną z takich form jest korzystanie z elektrycznych skuterów na minuty, jednak pomimo wyraźnego wzrostu ich popularności, w literaturze przedmiotu odnaleźć można jedynie kilka opracowań dotyczących determinant korzystania z tej formy mikromobilności. Celem artykułu jest poszerzenie wiedzy na temat motywów i barier w korzystaniu przez konsumentów z elektrycznych skuterów na minuty. W artykule omówiono wyniki badań przeprowadzonych w 2021 r. na próbie 352 polskich użytkowników. Najważniejszymi powodami korzystania z elektrycznych skuterów na minuty były wygoda i brak kosztów parkowania w mieście. Największymi barierami w wyborze tej formy przemieszczania się po mieści były te związane z bezpieczeństwem użytkowania.

Słowa kluczowe: współdzielona mikromobilność, współdzielona mobilność, elektryczne skutery na minuty, motywy, zachowania konsumentów, transport, innowacyjność konsumentów

JEL: 001, 018, 030

\section{Introduction}

Changes in the lifestyle of inhabitants, economic issues, and the growing importance of environmental issues in consumer choices are redefining mobility patterns in cities (Aguilera-García et al., 2019). For many years, changes in access to various forms of urban transport that are assumed to be consistent with the concept of sustainable development have been observed. An increasingly common trend around the world (including Poland) is the growing importance of low-emission transport and the introduction of short-term rental systems of bicycles, electric cars, e-scooters and moped e-scooters (Sojkin \& Michalak, 2019). The shift from "ownership" to "usership" — using resources made available "on demand" or sharing them with others - observed on the mobility market is a response 
to the negative consequences caused by mass motorization and the rapid increase of the number of private vehicles (Jurczak, 2019; Machado et al., 2018). Despite the increasing development of electric moped scooter sharing services/systems, the subject literature includes far fewer studies on the conditions of their use than in the case of other "sharing" services/systems (Aguilera-García et al., 2021; Bieliński \& Ważna, 2020; Eccarius \& Lu, 2018, Wortmann et al., 2021). On a dynamically changing market of transport services, understanding the mobility patterns of inhabitants is crucial for urban planners, administrators and transport service providers in order to adapt their services to the evolving needs of consumers (Aguilera-García et al., 2019). The main aim of this paper is to identify and assess the motives for and barriers to the use of electric moped scooter sharing services among the inhabitants of selected Polish cities and to define the main travel destinations using this form of transport.

\section{Electric moped scooter sharing services as a form of shared micro-mobility}

In recent years, a certain evolution of the transport services market has been observed, within which two main trends should be noted - shared mobility and electrification (Liao \& Correia, 2020). Among the forms of shared mobility, there are services related to shared micro-mobility, which is considered an innovative and "green" form of transport (Flores \& Jansson, 2021). Micro-mobility is an innovative urban transport solution and relates to trips over a shorter distance for personal transport by using low-speed modes of transportation e.g., bike, scooter/e-scooter, moped e-scooter, Segway, etc. (Lee et al., 2021; Eccarius \& Lu, 2020; Mitra \& Hess, 2020). The essence of shared micro-mobility is the temporary use of goods and services by consumers without having to own them (Machado et al., 2018). The use of shared micro-mobility services by consumers may contribute to reducing the problems faced by the authorities and inhabitants of many cities, e.g. excessive transport costs, traffic jams, air pollution, shortage of (parking) spaces and noise (Bieliński \& Ważna, 2020; Zhu et al., 2020). One of the results of the acceptance of this innovative form of urban transport may be a change in inhabitants' attitudes towards 
the necessity for private vehicle ownership and thus the inhibition of mass motorization and a reduction in the number of private cars (Abduljabbar et al., 2021). It should be noted that the rapid increase in the popularity of shared micro-mobility services was and still is a certain challenge for city authorities and public administration, e.g. in terms of appropriate legal regulations regarding the use of various forms of micro-mobility, the issue of adapting transport infrastructure, and ensuring the safety of pedestrians who are at risk of being hit by users of micro-mobility modes (Milakis et al., 2020; Reck \& Axhausen, 2021). In addition, attention is also drawn to the fact that rare metals as well as fossil fuel energy are used in the production of batteries to power micro-mobility electric modes (Milakis et al., 2020).

The motives for and barriers to using particular forms of micro-mobility differ from each other. For example, in the case of bike-sharing, the top facilitators to bikeshare use among users were: convenience, easy access to bikes, health benefits, economics benefits and fun/new experience. The top reported barriers were: no helmet, trouble with renting/returning, traffic safety concerns, bad weather and inconvenient stations (Franckle et al., 2020). On the other hand, the main benefits associated with the use of e-scooters by regular users in the USA include: they are faster than walking, they are convenient, they can be fun/relaxing, they are better in hot weather than walking and they allow users to reach places without the need to drive e.g. by car), are inexpensive to use, good for the environment or that users feel safer when using them (less likely to commit a crime on them). The main barriers to using e-scooters are related to safety concerns (e.g. hitting someone or being hit by someone, not enough safe places to ride, feeling unsteady / worrying about falling off), practicality-related barriers (e.g. no space for carrying luggage or transport other people, impractical for longer distances) and equipment-related barriers (e.g. broken e-scooters, trouble finding one when needed, battery not always charged, worrying that equipment will break / malfunction (Sanders et al., 2020). The main reasons for using e-scooters in Taiwan were primarily environmental issues, as well as convenience, the ability to access without owning, saving money, flexibility and pricing. The main barriers to the use of e-scooters were concerns about their condition (cleanliness, technical condition), availability / distance to the next e-scooter, price, helmet hygiene, and vehicle speed (Eccarius \& Lu, 2018). 
Despite the fact that the availability and popularity of electric moped scooter sharing services is growing rapidly in Europe (Wortmann et al., 2021), in the literature on the subject, there are few studies on the motives for and barriers to using this micro-mobility mode. The main reasons for using a moped scooter-sharing system listed by Spanish consumers were: the benefits of easily parking the moped, flexibility mobility/avoiding traffic jams, a well-functioning system, competitive pricing and environmental awareness (Aguilera-García et al., 2021).

It should be borne in mind that the use of various modern urban mobility systems is possible after meeting certain criteria for a given form, e.g. in the case of bike-sharing in Poznan - people under the age of 13 may use bikes only under the care of a parent or legal guardian, for people from 10 to 18 years of age to drive an electric scooter, it is required to have the same qualifications as for cycling, i.e. a bicycle card or driving license of categories AM, A1, B1 or T, in the case of car-sharing it is obligatory to have driving license, and in the case of moped e-scooters legal age and the use of a helmet are required.

\section{Research design}

An empirical study verifying the motives, barriers and goals of using electric moped scooter sharing services was conducted in cooperation with Blinkee $^{1}$ in the first half of 2021 using the online survey technique in Google Forms. The areas of empirical research included the following scopes:

a) subjective - electric moped scooter users (having an active account in the application, regardless of the frequency of using the moped scooters),

b) subject - frequency of using the selected form of urban transportation, motives, barriers and goals of using city electric moped scooter sharing services,

c) spatial - selected voivodeship capital cities of Poland: Białystok, Bydgoszcz, Gdańsk, Gdynia, Katowice, Kraków, Lublin, Łódź, Poznań, Warsaw and Wrocław,

d) temporary - first half of 2021 . 
The size of the research sample was 352 observations $(\mathrm{N}=352)$. In the process of selecting the research sample, purposive selection was used, where the basic criterion was to have an active account in the Blinkee application for renting electric moped scooters. The analysis of the empirical data obtained was carried out using the IBM SPSS Statistics program - the response distribution indicators, statistical description indicators were calculated, and selected methods of analysis of variance and the method of exploratory factor analysis were used.

The research sample was dominated mainly by men $(93.5 \%$ of all respondents) and people aged 25-34 (42.6\% of all respondents), with higher education ( $64.8 \%$ of all respondents), with a material status above national average (52.6\% of all respondents). The structure of the research sample, taking into account selected characteristics of the respondents, is presented in the table below (Tab. 1).

\section{Table 1. Structure of the research sample}

\begin{tabular}{|c|c|c|c|c|}
\hline \multirow{2}{*}{\multicolumn{2}{|c|}{$\begin{array}{l}\text { Characteristics } \\
\text { of the respondents }\end{array}$}} & \multirow{2}{*}{ Overall (\%) } & \multicolumn{2}{|c|}{$\begin{array}{l}\text { The frequency of using } \\
\text { electric moped scooters (\%) }\end{array}$} \\
\hline & & & not at all & rarely, \\
\hline Gender & $\begin{array}{l}\text { woman } \\
\text { man } \\
\text { overall }\end{array}$ & $\begin{array}{r}6.5 \\
93.5 \\
100.0\end{array}$ & $\begin{array}{r}5.1 \\
94.9 \\
100.0\end{array}$ & $\begin{array}{r}7.0 \\
93.0 \\
100.0\end{array}$ \\
\hline Age & $\begin{array}{l}18-24 \text { years } \\
25-34 \text { years } \\
35-44 \text { years } \\
45 \text { and more } \\
\text { overall }\end{array}$ & $\begin{array}{r}20.5 \\
42.6 \\
25.9 \\
11.1 \\
100.0\end{array}$ & $\begin{array}{r}22.8 \\
35.4 \\
27.8 \\
13.9 \\
100.0\end{array}$ & $\begin{array}{r}19.8 \\
44.7 \\
25.3 \\
10.3 \\
100.0\end{array}$ \\
\hline Education & $\begin{array}{l}\text { elementary, lower secondary, vocational } \\
\text { secondary education } \\
\text { higher education } \\
\text { overall }\end{array}$ & $\begin{array}{r}6.3 \\
29.0 \\
64.8 \\
100.0\end{array}$ & $\begin{array}{r}6.3 \\
31.6 \\
62.0 \\
100.0\end{array}$ & $\begin{array}{r}6.2 \\
28.2 \\
65.6 \\
100.0\end{array}$ \\
\hline Material status & $\begin{array}{l}\text { below the national average } \\
\text { the national average } \\
\text { above the national average } \\
\text { overall }\end{array}$ & $\begin{array}{r}12.2 \\
35.2 \\
52.6 \\
100.0\end{array}$ & $\begin{array}{r}13.9 \\
43.0 \\
43.0 \\
100.0\end{array}$ & $\begin{array}{r}11.7 \\
33.0 \\
55.3 \\
100.0\end{array}$ \\
\hline
\end{tabular}


In assessing the motives for electric moped scooter sharing services, 17 factors were verified (tab. 2). The significance of the selected motifs was assessed using a 5-point Likert scale, on which the values were scaled from 1 - definitely not, to 5 - definitely yes. For the purposes of the study, it was assumed that the distances between the categories on the Likert scale are equal. Such an assumption is common in the social sciences and allows the use of parametric tests. The analysis of mean values allows the most and least important motives from the perspective of the respondents to be identified. The set of the most important motives included the flexibility of using moped e-scooters $\left(\operatorname{mean}_{7}=4.19\right)$, making it easier to travel $\left(\operatorname{mean}_{8}=\right.$ $=4.17)$, the possibility of reaching the destination point directly $\left(\operatorname{mean}_{11}=\right.$ $=4.05)$, independence from public transport $\left(\right.$ mean $\left._{16}=3.91\right)$ and time savings compared to the use of other forms of urban mobility $\left(\operatorname{mean}_{17}=3.86\right)$. The average significance of all the identified motives for using electric moped scooter sharing services is presented in the table below (Tab. 2).

Additionally, the significance of the selected motives for using electric moped scooter sharing services was compared between the two groups of respondents - the first group includes respondents who do not use moped e-scooters or use moped e-scooters very rarely (less than once a month), while the second group includes respondents who declare more frequent use of moped e-scooters. The results obtained clearly indicate the higher importance of the surveyed motives in the group of respondents who use electric moped scooter sharing services at least once a month - the only motive, the importance of which is similar in both groups of the respondents, is the lack of the need to incur additional costs of parking in the city $\left(\operatorname{mean}_{4 \_\mathrm{N}} \approx \operatorname{mean}_{4-\mathrm{Y}}-\right.$ Tab. 2$)$.

The next step in the research procedure was to assess the importance of barriers to using electric moped scooter sharing services (the relevant data presented in Tab. 3). The significance of these examined barriers was assessed using a 5-point Likert scale, on which the values were scaled from 1 - definitely no, to 5 - definitely yes. In the context of barriers to using moped e-scooters, respondents primarily focused on the availability of scooters in places where they would like to use them $\left(\operatorname{mean}_{4}=3.89\right)$, weather conditions $\left(\operatorname{mean}_{5}=3.84\right)$, travel price $\left(\operatorname{mean}_{6}=\right.$ $=3.36$ ) and the concern about the cleanliness and hygiene of scooters $\left(\operatorname{mean}_{8}=3.11\right)$. 


\section{Table 2. The importance of the motives for using electric moped scooter sharing services}

\begin{tabular}{|c|c|c|c|}
\hline Motives for using electric moped scooters & $\begin{array}{c}\text { mean } \\
\text { overall }\end{array}$ & $\begin{array}{l}\text { mean } \\
\mathbf{N} \mid \mathbf{Y}\end{array}$ & t-test \\
\hline 1. due to travel costs (compared to other forms of transport) & 2.74 & $2.01<2.95$ & $-5.595^{* * *}$ \\
\hline $\begin{array}{l}\text { 2. because I do not want to spend money on buying my own vehicle (car, } \\
\text { motorbike, scooter) }\end{array}$ & 2.29 & $1.99<2.38$ & $-2.188^{*}$ \\
\hline $\begin{array}{l}\text { 3. because I do not want to spend money on maintaining my } \\
\text { own vehicle (car, motorcycle, scooter) }\end{array}$ & 2.33 & $2.03<2.42$ & $-2.170^{*}$ \\
\hline 4. due to the lack of costs of parking in the city & 3.19 & $2.97 \approx 3.25$ & - \\
\hline 5. because there is no need to look for free parking spaces in the city & 3.57 & $3.23<3.67$ & $-2.294^{*}$ \\
\hline $\begin{array}{l}\text { 6. because it is a more convenient solution than other forms of urban } \\
\text { mobility }\end{array}$ & 3.78 & $3.18<3.96$ & $-5.359 * * *$ \\
\hline 7. because it is a very flexible solution (I use it when I need it) & 4.19 & $3.87<4.28$ & $-2.835^{* *}$ \\
\hline 8. because it makes it easier for me to travel & 4.17 & $3.70<4.31$ & $-4.626^{* * *}$ \\
\hline $\begin{array}{l}\text { 9. due to the level of development of the public transport network } \\
\text { (MPK, rail) }\end{array}$ & 2.44 & $2.08<2.54$ & $-2.897 * *$ \\
\hline $\begin{array}{l}\text { 10. due to the quality of public transport services (safety, cleanliness, } \\
\text { punctuality, etc.) }\end{array}$ & 2.54 & $2.11<2.66$ & $-3.199 * *$ \\
\hline 11. due to the possibility of reaching the destination point directly & 4.05 & $3.65<4.16$ & $-3.161^{* *}$ \\
\hline 12. to travel in a more environmentally friendly way & 3.00 & $2.56<3.13$ & $-3.138^{* *}$ \\
\hline $\begin{array}{l}\text { 13. because in my opinion it contributes to the improvement of air } \\
\text { quality in the city }\end{array}$ & 2.74 & $2.38<2.84$ & $-2.676^{* *}$ \\
\hline 14. due to the ease of driving/use & 3.45 & $2.95<3.59$ & $-4.001 * * *$ \\
\hline 15. not to get stuck in traffic jams (speed of movement around the city) & 3.81 & $3.16<3.99$ & $-5.049 * * *$ \\
\hline $\begin{array}{l}\text { 16. because I don't have to worry about the public transport timetable } \\
\text { and whether I will be on time for the tram/bus/train }\end{array}$ & 3.91 & $3.58<4.01$ & $-2.582^{*}$ \\
\hline $\begin{array}{l}\text { 17. because of the time savings - I reach my destination faster } \\
\text { by scooter than using other forms of traveling }\end{array}$ & 3.86 & $3.27<4.04$ & $-4.954 * * *$ \\
\hline
\end{tabular}

- motives for using electric moped scooters - categories on the Likert scale: 1. definitely not, 2. rather not, 3. neither "yes" nor "no", 4. rather yes, 5. definitely yes.

- use of electric moped scooters: $\mathrm{N}$ - not at all or very rarely (less than once a month), $\mathrm{Y}$ — from rarely (1-3 times a month) to very often (daily or almost daily)

- t-test — value of the t-test; $\mathrm{p}$ - significance level; * $\mathrm{p} \leq 0.05 ; * * \mathrm{*} \leq 0.01 ; * * \mathrm{*} \leq 0.001$ 


\section{Table 3. The importance of the barriers to using electric moped scooter sharing services}

\begin{tabular}{l|c|c|c}
\hline \multicolumn{1}{c|}{ Barriers to using electric scooters } & $\begin{array}{c}\text { mean } \\
\text { overall }\end{array}$ & $\begin{array}{c}\text { mean } \\
\mathbf{N} \text { | Y }\end{array}$ & t-test \\
\hline 1. fear for safety while driving & 2.54 & $2.59 \approx 2.53$ & - \\
2. concern about the security of personal data & 2.16 & $2.15 \approx 2.17$ & - \\
3. fear of liability/costs in the event of an accident or collision & 2.77 & $2.78 \approx 2.77$ & - \\
4. the number of scooters in the places I would like to use them & 3.89 & $3.56<3.99$ & $-2.687^{* *}$ \\
5. weather conditions & 3.84 & $3.71 \approx 3.88$ & - \\
6. the price of the trip & 3.36 & $3.59 \approx 3.30$ & - \\
7. concern about the technical condition of scooters & 2.93 & $2.71 \approx 3.00$ & - \\
8. concern about the cleanliness/hygiene of scooters and helmets & 3.11 & $3.04 \approx 3.13$ & - \\
9. I prefer other forms of urban transportation & 2.36 & $2.95>2.18$ & $5.592^{* * *}$ \\
10. problems with the correct operation of the mobile application & & & - \\
(making a reservation, accounting for a ride, etc.) & 2.67 & $2.85 \approx 2.62$ & - \\
11. intuitiveness and ease of use of the mobile application & 2.34 & $2.38 \approx 2.33$ & - \\
12. difficulty in driving/using a scooter & 1.77 & $2.09>1.68$ & $2.803^{* *}$ \\
13. not enough space to store things that I need to take with me & 2.49 & $2.44 \approx 2.50$ & - \\
14. battery level in the scooter & 2.94 & $2.63<3.03$ & $-2.353^{* *}$ \\
15. kilometers that can be traveled (range) & 2.63 & $2.51 \approx 2.66$ & - \\
16. the size of the scooter & 1.99 & $2.06 \approx 1.97$ & - \\
17. tire inflation level, amortized suspension, etc. & 2.33 & $2.24 \approx 2.36$ & - \\
\hline
\end{tabular}

- barriers to using electric moped scooters - categories on the Likert scale: 1. definitely not, 2. rather not, 3. neither "yes" nor "no", 4. rather yes, 5. definitely yes.

- use of electric moped scooters: $\mathrm{N}$ - not at all or very rarely (less than once a month), $\mathrm{Y}$ - from rarely (1-3 times a month) to very often (daily or almost daily)

- t-test - value of the t-test; $\mathrm{p}$ - significance level; ${ }^{*} \mathrm{p} \leq 0.05 ;{ }^{*} \mathrm{p} \leq 0.01 ; * * \mathrm{p} \leq 0.001$

The comparison of the significance of the identified barriers between the groups of respondents (not using or rarely using and using moped e-scooters at least once a month) allowed for the identification of only a few statistically significant differences - in the group of active scooter users, the number of scooters in places where they can be used $\left(\operatorname{mean}_{4-\mathrm{N}}<\right.$ $\left.<\operatorname{mean}_{4_{-} \mathrm{Y}}\right)$ and the battery level in the scooter $\left(\operatorname{mean}_{14_{-} \mathrm{N}}<\operatorname{mean}_{14_{-} \mathrm{Y}}\right)$ are more important, while in the group of people who do not or occasionally use moped e-scooters, preferences regarding other forms of urban transportation $\left(\operatorname{mean}_{9_{-} \mathrm{N}}>\operatorname{mean}_{9_{-} \mathrm{Y}}\right)$ and difficulties in driving and using scooters $\left(\operatorname{mean}_{12 \_\mathrm{N}}>\right.$ mean $\left._{12_{-} \mathrm{Y}}\right)$ are more important. 
In the next step of the research procedure, based on the frequency of using electric moped scooter sharing services, the significance of the purposes of their rental was verified (data presented in Tab. 4). The assessment was made using a 5-point Likert scale, on which the values were scaled from 1 not at all or very rarely (less frequently than once a month), to 5 - very often (every day or almost every day). The mean values obtained (mean values $\leq$ $\leq 2.33$ ) indicate a relatively rare use of this method of urban transportation - the key importance in this context seems to be the time of the study coinciding with the COVID-19 pandemic and the related remote work and teaching at all levels of education. Nevertheless, the results indicate that the use of electric moped scooter sharing services occurs most often when dealing with various matters $\left(\operatorname{mean}_{6}=2.33\right)$, traveling to or from a place where you spend your free time $\left(\operatorname{mean}_{7}=2.22\right)$, restaurants or cafes $\left(\operatorname{mean}_{9}=2.09\right)$, cinema, theatre, opera or concert $\left(\operatorname{mean}_{8}=2.07\right)$. It is relatively popular to use this micro-mobility urban transportation mode when "driving" $\left(\operatorname{mean}_{11}=\right.$ $=2.06)$ and visiting family or friends $\left(\operatorname{mean}_{5}=2.04\right)$.

\section{Table 4. The importance of the purposes of using electric moped scooter sharing services}

\begin{tabular}{l|c|c|c}
\hline \multicolumn{1}{c|}{ Purposes of using electric moped scooters } & mean overall & mean N | Y & t-test \\
\hline 1. access to or from public transport points & 1.41 & $1.16<1.49$ & $-2.935^{* *}$ \\
2. travel to or from work & 1.97 & $1.30<2.17$ & $-6.016^{* * * *}$ \\
3. travel to or from school/university & 1.42 & $1.18<1.49$ & $-2.707^{* *}$ \\
4. transport to or from the store/shopping & 1.68 & $1.32<1.78$ & $-3.590^{* * *}$ \\
5. visiting family or friends & 2.04 & $1.39<2.23$ & $-5.596^{* * * *}$ \\
6. dealing with various matters "in the city" (e.g. official) & 2.33 & $1.70<2.51$ & $-5.599^{* * *}$ \\
7. transport to or from a place where you spend your free time & & & \\
$\quad$ - e.g. to a park, to a lake & 2.22 & $1.81<2.34$ & $-3.383^{* * *}$ \\
8. transport to or from the cinema/cultural events & & & \\
$\quad$ (theatre, opera, concert, etc.) & 2.07 & $1.52<2.23$ & $-4.639^{* * *}$ \\
9. transport to or from restaurants/cafes & 2.09 & $1.70<2.21$ & $-3.371^{* * *}$ \\
10. transport to or from a bar/disco & 1.87 & $1.46<1.99$ & $-3.533^{* * *}$ \\
11. a ride (without a clearly defined goal) & 2.06 & $1.75<2.15$ & $-2.445^{*}$ \\
\hline
\end{tabular}

- goals for using electric moped scooters - categories on the Likert scale: 1.not at all or very rarely (less than once a month), 2.rarely (1-3 times a month), 3.average (once a week), 4.often (2-3 times a week), 5.very often (every day or almost every day)

- use of electric moped scooters: $\mathrm{N}$ - not at all or very rarely (less than once a month), $\mathrm{Y}$ - from rarely (1-3 times a month) to very often (daily or almost daily)

- t-test - value of the t-test; $\mathrm{p}$ - significance level; *p $\leq 0.05 ;{ }^{* *} \mathrm{p} \leq 0.01 ; * * \mathrm{*} \leq 0.001$ 
The comparison of the average importance of the purposes of using electric moped scooter sharing services between groups of respondents who rarely or occasionally, or at least once a month, use this form of urban transportation clearly indicates a greater role played by all the goals studied in the group of active users. Such an assessment, despite the period of the COVID-19 pandemic, may indicate the purposefulness of the development of this micro-mobility form of urban transportation.

In the last step of the research procedure, the original sets of measurable variables (motives, barriers and purposes of using electric moped scooter sharing services) were reduced using the exploratory factor analysis method - this allowed the original sets to be reduced, including 17 variables to 5 components in the case of motives, in the case of barriers, 17 variables to 3 components, while for the purposes of using scooters, 11 variables to 2 components $^{2}$. A semantic interpretation was given to new components (results presented in Tab. 5).

\section{Table 5. Determinants of using electric moped scooter sharing services - results of exploratory factor analysis}

Variables

factor

loadings

Motives for using electric moped scooter sharing services $(\mathrm{KMO}=0.830 ; \mathrm{p}=0.000 ; \mathrm{TVE}=77.94 \%)$

component 1 - the convenience of this mobility mode $\left(\operatorname{mean}_{\mathrm{CMPT} 1}=\mathbf{3 . 9 7}\right)$

6 . because it is a more convenient solution than other forms of urban mobility

0.703

7. because it is a very flexible solution (I use it when I need it)

0.736

8 . because it makes it easier for me to travel

11. due to the possibility of reaching the destination point directly

0.852

15. not to get stuck in traffic jams (speed of movement around the city)

0.697

16. because I don't have to worry about the public transport timetable and whether I will be on time

0.745

for the tram /bus/train

17. because of the time savings - I reach my destination faster by scooter than using other forms

0.814 of traveling

component $2-$ no vehicle purchase and maintenance costs $\left(\operatorname{mean}_{\mathrm{CMPT} 2}=\mathbf{2 . 3 1}\right)$

2 . because I do not want to spend money on buying my own vehicle (car, motorbike, scooter)

3. because I do not want to spend money on maintaining my own vehicle (car, motorcycle, scooter)

component $3-$ no city parking costs $\left(\right.$ mean $\left._{\text {CMPT3 }}=3.38\right)$

4. due to the lack of costs of parking in the city

5 . because there is no need to look for free parking spaces in the city

component $4-$ environmental incentives $\left(\right.$ mean $\left._{\mathrm{CMPT} 4}=2.87\right)$

12. to travel in a more environmentally friendly way

0.882 


\section{Cont. table 5}

\begin{tabular}{l|c}
\hline \multicolumn{1}{c|}{ Variables } & $\begin{array}{c}\text { factor } \\
\text { loadings }\end{array}$ \\
\hline $\begin{array}{l}\text { 13. because in my opinion it contributes to the improvement of air quality in the city } \\
\text { component } \mathbf{5}-\text { quality of public transport (mean } \mathbf{C M P T 5}=\mathbf{2 , 4 9 )}\end{array}$ & 0.894 \\
\hline $\begin{array}{l}\text { 9. due to the level of development of the public transport network }(\mathrm{MPK}, \text { rail) } \\
\text { 10. due to the quality of public transport services (safety, cleanliness, punctuality, etc.) }\end{array}$ & 0.871 \\
\hline
\end{tabular}

Barriers to using electric moped scooter sharing services $(\mathrm{KMO}=0.747 ; \mathrm{p}=0.000 ; \mathrm{TVE}=65.86 \%)$

component 1 - safety of use $\left(\right.$ mean $\left._{\mathrm{CMPT1}}=\mathbf{2 . 8 3}\right)$

1. fear for safety while driving

2. concern about the security of personal data

3. fear of liability/costs in the event of an accident or collision

5. weather conditions

component $2-$ scooter parameters $\left(\right.$ mean $\left._{\mathrm{CMPT} 2}=\mathbf{2 . 5 2}\right)$

14. battery level in the scooter

15. kilometers that can be traveled (range)

16. the size of the scooter

component $3-$ mobile application support $\left(\operatorname{mean}_{\mathrm{CMPT} 3}=\mathbf{2 . 5 0}\right)$

10. problems with the correct operation of the mobile application

(making a reservation, accounting for a ride, etc.)

11. intuitiveness and ease of use of the mobile application

Purposes of using electric moped scooter sharing services $(\mathrm{KMO}=0.879 ; \mathrm{p}=0.000 ; \mathrm{TVE}=62.02 \%)$

component 1 - recreational and organizational purposes $\left(\operatorname{mean}_{\mathrm{CMPT1}}=\mathbf{2 . 1 0}\right)$

5. visiting family or friends

6. dealing with various matters "in the city" (e.g. official)

7. transport to or from a place where you spend your free time - e.g. to a park, to a lake

8. transport to or from the cinema/cultural events (theatre, opera, concert, etc.)

9. transport to or from restaurants/cafes

10. transport to or from a bar/disco

component 2 - formal and official purposes $\left(\operatorname{mean}_{\mathrm{CMPT2}}=1.62\right)$

1. access to or from public transport points

2. travel to or from work

3. travel to or from school/university

4. transport to or from the store/shopping

KMO - Kaiser-Meyer-Olkin Test for Sampling Adequacy; TVE — Total Variance Explained $\mathrm{p}$ — significance level; mean — mean; CMPT — component

As in the case of measurable variables, the average values of the newly distinguished components were compared between the group of 
respondents who do not use scooters or use moped e-scooters very rarely (less than once a month) and the group declaring more frequent use of electric moped scooters (Tab. 6).

\section{Table 6. Assessment of the components of using electric moped scooter sharing services}

Use of electric scooters mean overall $\quad$ mean $\mathbf{N} \mid \mathbf{Y} \quad$ t-test

Motives for using electric moped scooter sharing services

component 1 - the convenience of this mobility mode

component $2-$ no vehicle purchase and maintenance costs

3.97

2.31

3.38

component 3 - no city parking costs

2.87

component 4 - environmental incentives

2.49

\begin{tabular}{l|c}
$3.49<4.11$ & $-5.247^{* * *}$ \\
$2.01<2.40$ & $-2.185^{*}$ \\
$3.10<3.46$ & $-2.027^{*}$ \\
$2.47<2.98$ & $-3.056^{* *}$ \\
$2.09<2.60$ & $-3.259^{* * *}$
\end{tabular}

Barriers to using electric moped scooter sharing services

component 1 - safety of use

2.83

component 2 - scooter parameters

2.52

component $3-$ mobile application support

2.50

$2.81 \approx 2.84$

$2.40 \approx 2.56$

$2.61 \approx 2.47$

\section{Purposes of using electric moped scooter sharing services}

component 1 - recreational and organizational purposes

2.10

$1.59<2.25$

component 2 - formal and official purposes

1.62

$1.24<1.73$

- goals of using electric moped scooters - categories on the Likert scale: 1.not at all or very rarely (less than once a month),

2.rarely (1-3 times a month), 3.average (once a week), 4.often (2-3 times a week), 5.very often (every day or almost every day)

- use of electric moped scooters: $\mathrm{N}$ - not at all or very rarely (less than once a month), $\mathrm{Y}$ - from rarely (1-3 times

a month) to very often (daily or almost daily)

- t-test - value of the t-test; $\mathrm{p}$ - significance level; * $\mathrm{p} \leq 0.05 ;{ }^{* *} \mathrm{p} \leq 0.01 ;{ }^{* * *} \mathrm{p} \leq 0.001$

The analysis of the results confirms the regularities identified at the stage of the results analysis in terms of directly observable variables. The most important reasons for using the electric moped scooter sharing services included the convenience of this mobility mode (mean $=3.97$ ) and no city parking costs (mean $=3.38$ ). The biggest barriers to choosing this micro-mobility mode for Polish consumers were those related to the safety of use (mean $=2.83$ ). The comparison of the mean values of the components between the groups of respondents surveyed indicates the greater importance of the motives and goals of using electric moped scooter sharing services in the group of respondents using them at least once a month. On the other hand, the analysis of the significance of the barriers 
did not allow the identification of statistically significant differences between the surveyed groups of respondents - the absence of differences in this respect may indicate the need to emphasize the advantages (motives) of using moped e-scooters as the basic determinants that can increase the popularity of this method of urban transportation.

\section{Summary}

The analysis of the results shows that there are specific challenges faced by administrators of electric moped scooter sharing services. In this context, the most important thing is to identify the most attractive routes for moped e-scooter users, which should ensure the availability of scooters and minimize the costs associated with their possible logistics to these places. This is confirmed by the analysis of the purposes of using electric moped scooters, which indicates the informal nature of scooter trips. At this point, however, attention should be paid to the period of the COVID-19 pandemic, which certainly influenced the way a typical work or study day was organized by residents of large cities.

The analysis of barriers, in turn, indicates the occurrence of concerns related primarily to the safety of use, the availability of moped e-scooters and weather conditions. The last of these barriers indicates fluctuations in the demand for this micro-mobility mode, both irregular (e.g. rainfall in summer) and seasonal (e.g. low temperatures in late autumn and early spring), which certainly translates into economic calculations for the businesses providing the infrastructure of electric moped scooters.

The analysis of the importance of the goals of using electric moped scooter sharing services shows the potential for the development of the scooter market in large cities in Poland - this is indicated by higher average values in terms of goals of using scooters in the group of people using electric moped scooter sharing services at least once a month. The relatively low average values in the assessment of the goals of using 
scooters indicate the need to emphasize the advantages and minimize the significance of the identified barriers to using scooters identified in the groups of current and potential users - this should allow for a growing substitution in comparison with other forms of mobility in large cities.

\section{Limitations and future research directions}

It should be noted that due to the lack of a large number of studies on the determinants and scope of use of moped e-scooters by consumers, future studies should be conducted to advance knowledge on the topic and fill the research gap. Future research topics could focus on identification of a potential relationship between user experience and willingness to use electric moped scooter sharing services in the future. A certain limitation of the research carried out for the purpose of writing this paper is the spatialsubjective scope covering only Polish consumers, hence an interesting idea would be comparative research in other countries. Cross-Country comparative research could identify differences in consumer behavior between users in different countries. Due to the selection sampling method and the size of the research sample, the results are not representative of the entire population of Polish electric moped scooter sharing services users. It should also be remembered that the study was conducted during the COVID-19 pandemic, so it is worth comparing the behavior of consumers regarding the use of electric moped scooter sharing services during and after the pandemic.

\section{Endnotes}

${ }^{1}$ Blinkee is the leader of electric moped scooter sharing market in Poland. The company has over half a million registered users in Poland and its portfolio also includes other micro-mobility modes.

2 The minimum values of the factor loadings were set at the level of 0.6. 


\section{References}

1. Abduljabbar, R. L., Liyanage, S. \& Dia, H. (2021). The role of micro-mobility in shaping sustainable cities: A systematic literature review. Transportation Research Part D: Transport and Environment, 92, https://doi.org/10.1016/j.trd.2021.102734

2. Aguilera-García, Á., Gomez, J., Sobrino, N., \& Díaz, J. J. V. (2021). Moped Scooter Sharing: Citizens' Perceptions, Users' Behavior, and Implications for Urban Mobility. Sustainability, 13(12), 6886. https://doi:10.3390/su13126886

3. Aguilera-García, Á., Gomez, J. \& Sobrino, N. (2020). Exploring the adoption of moped scooter-sharing systems in Spanish urban areas. Cities, 96, https://doi.org/ 10.1016/j.cities.2019.102424

4. Bieliński, T., \& Ważna, A. (2020). Electric Scooter Sharing and Bike Sharing User Behaviour and Characteristics. Sustainability, 12(22), 9640. https:/doi:10.3390/ su12229640

5. Eccarius, T., \& Lu, C-C. (2018). Exploring Consumer Reasoning in Usage Intention for E-Scooter Sharing. Transportation Planning Journal, 47(4), 271-296. https://doi.org/10.6402/TPJ

6. Eccarius, T., \& Lu, C-C. (2020). Adoption intentions for micro-mobility - Insights from electric scooter sharing in Taiwan. Transportation Research Part D: Transport and Environment, 84, https://doi.org/10.1016/j.trd.2020.102327

7. Flores, P. J., \& Jansson, J. (2021). The role of consumer innovativeness and green perceptions on?green innovation use: The case of shared e-bikes and e-scooters. Journal of Consumer Behaviour, 1-14. https://doi.org/10.1002/cb.1957

8. Franckle, R. L., Dunn, C. G., Vercammen, K. A., Dai, J., Soto, M. J. \& Bleich, S. N. (2020). Facilitators and barriers to bikeshare use among users and non-users in a socioeconomically diverse urban population. Preventive Medicine Reports, 20, https://doi.org/10.1016/j.pmedr.2020.101185

9. Jurczak M. (2019). Koncepcje zrównoważonej logistyki miejskiej w wybranych polskich miastach [Concepts of Sustainable Urban Logistics in Selected Polish Cities]. Ekonomika i Organizacja Logistyki 4(2), DOI: 10.22630/EIOL.2019.4.2.11

10. Lee, H., Baek, K., Chung, J-H. \& Kim, J. (2021). Factors affecting heterogeneity in willingness to use e-scooter sharing services. Transportation Research Part D: Transport and Environment, 92, https://doi.org/10.1016/j.trd.2021.102751

11. Liao, F. \& Correia, G. (2020). Electric carsharing and micromobility: A literature review on their usage pattern, demand, and potential impacts. International Journal of Sustainable Transportation, DOI: 10.1080/15568318.2020.1861394

12. Machado, C., de Salles Hue, N., Berssaneti, F., \& Quintanilha, J. (2018). An Overview of Shared Mobility. Sustainability, 10(12), 4342. http://doi:10.3390/su10124342

13. Malarska A. (2005). Statystyczna analiza danych wspomagana programem SPSS [Statistical Data Analysis Aided by SPSS]. Wydawnictwo SPSS Polska, Kraków.

14. Milakis, D., Gebhardt, L., Ehebrecht, D. \& Lenz, B. (2020) Is micro-mobility sustainable? An overview of implications for accessibility, air pollution, safety, physical activity and 
subjective wellbeing. In: Carey Curtis (red.), Handbook of Sustainable Transport, 180-189. Edward Elgar Publishing Ltd.

15. Mitra, R. \& Hess, P. M. (2021). Who are the potential users of shared e-scooters? An examination of socio-demographic, attitudinal and environmental factors. Travel Behaviour and Society, 23, https://doi.org/10.1016/j.tbs.2020.12.004

16. Reck, D. J. \& Axhausen, K. W. (2021). Who uses shared micro-mobility services? Empirical evidence from Zurich, Switzerland. Transportation Research Part D: Transport and Environment, 94, https://doi.org/10.1016/j.trd.2021.102803

17. Sanders, R. L., Branion-Calles, M. \& Nelson, T. A. (2020). To scoot or not to scoot: Findings from a recent survey about the benefits and barriers of using E-scooters for riders and non-riders. Transportation Research Part A: Policy and Practice, 139, https://doi.org/10.1016/j.tra.2020.07.009

18. Sojkin, B. \& Michalak, S. (2019). Innowacyjność zachowań mieszkańców aglomeracji poznańskiej na rynku usług transportowych [Innovative Behavior of the Inhabitants of Poznań Agglomeration on the Market of Transport Services]. Marketing Instytucji Naukowych i Badawczych, 33, DOI: 10.2478/minib-2019-0040

19. Wortmann, C., Syré, A. M., Grahle, A., \& Göhlich, D. (2021). Analysis of Electric Moped Scooter Sharing in Berlin: A Technical, Economic and Environmental Perspective. World Electric Vehicle Journal, 12(3), 96. doi:10.3390/wevj12030096

20. Zhu, R., Zhang, X., Kondor, D., Santi, P. \& Ratti, C. (2020). Understanding spatiotemporal heterogeneity of bike-sharing and scooter-sharing mobility. Computers, Environment and Urban Systems, 81, https://doi.org/10.1016/ j.compenvurbsys.2020.101483

Paweł Bartkowiak, Poznań University of Economics and Business, Poland - PhD in economic sciences, Assistant Professor at the Department of Strategic Management, Poznań University of Economics and Business. His main research interests include processes of value cocreation, determinants of consumers' market behavior, project management and strategic decision-making at enterprises. He teaches courses in strategic management, project management and market and marketing research.

Szymon Michalak, Poznań University of Economics and Business, Poland - PhD in economic sciences, Assistant Professor in the Product Marketing Department of Poznań University of Economics and Business. His main research interests include consumer attitudes towards product innovation and consumer involvement in value co-creation. A team member on projects with EU funding, as well as projects for enterprises, local government units and the Polish Ministry of Agriculture and Rural Development. He teaches such subjects as Innovation Management, Product Management, Marketing Research, and Enterprise Management. 
Maciej Młodzik, Piasecki University of Physical Education in Poznań, Poland - PhD in medical and health Sciences, in the field of Physical Education Culture Studies. His research revolves around attitudes towards physical activity, especially in the aquatic environment. Staff member at a local government unit in Poznań, a member of organizing committees and an organizer and commentator of many sporting events. 